\title{
HUBUNGAN PEMBERIAN ASI EKSKLUSIF DENGAN KEJADIAN DIARE PADA BAYI DI WILAYAH KERJA PUSKESMAS CIBADAK KABUPATEN LEBAK TAHUN 2019
}

\author{
THE RELATION OF EXCLUSIVE BREAST MILK FEEDING \\ WITH DIARRHEA OCCURRENCE ON BABIES AT WORKING AREA OF \\ CIBADAK PUBLIC HEALTH CENTER LEBAK REGENCY YEAR 2019
}

\author{
Omo Sutomo, Een Sukaedah, Tutik Iswanti \\ Poltekkes Kemenkes Banten \\ Korespondensi : omo.sutomo@poltekkesbanten.ac.id
}

\begin{abstract}
Diarrhea until nowadays is still being a public health problem, its occurrence keeps being the main disease towards babies in Indonesia. The research purpose is to find out the relation of exclusive breast milk feeding with diarrhea occurrence on babies at working area of Cibadak Public Health Center Lebak Regency year 2019. This research is an analytical research with observational design and cross sectional approach. The research samples are 89 mothers who have babies of age 7-12 months. Samples are taken using proportional random sampling technique. The data analysis is done step by step. Firstly, it is done in uni-variable which aims to obtain proportion image of each variable. Then, it is done in bi-variable which aims to acknowledge the relation of the independent and dependent variable. The statistical test applied is chi square test. To discover the relationship meaning, $\alpha$ value of 0.05 is utilized. The research result shows that there are still many babies who suffer from diarrhea (36.0\%) and babies who are not fed with exclusive breast milk (47.2 \%). There is a meaningful relation between exclusive breast milk feeding with diarrhea occurrence on babies (0.000) in which mothers who do not feed exclusive breast milk to their babies possess a higher risk of more than 8 times for their babies to suffer from diarrhea. The effort of health education regarding the importance of exclusive breast milk feeding is needed, as well as prevention and first aids of diarrhea on babies, and accompaniment for the mothers during exclusive breast milk feeding period with the involvement of POSYANDU cadres in the implementation.
\end{abstract}

Keywords: Diarrhea on babies, exclusive breast milk

\begin{abstract}
ABSTRAK
Diare sampai saat ini masih menjadi masalah kesehatan masyarakat, kejadiannya masih menjadi penyakit utama pada bayi di Indonesia. Penelitian ini bertujuan untuk mengetahui hubungan pemberian ASI eksklusif dengan kejadian diare pada bayi di wilayah kerja Puskesmas Cibadak Kabupaten Lebak tahun 2019. Penelitian ini merupakan penelitian analitik dengan desain observasional dengan pendekatan cross sectional. Sampel penelitian ini ialah ibu yang memiliki bayi berumur 7-12 bulan sebanyak 89 orang. Sampel diambil dengan teknik proporsional random sampling. Analisis data dilakukan secara bertahap, mula-mula secara univariat bertujuan untuk memperoleh gambaran proporsi masing-masing variabel, kemudian bivariat bertujuan untuk mengetahui hubungan variabel independen dan variabel dependen. Uji statistik digunakan uji chi square. Untuk mengetahui kemaknaan
\end{abstract}


hubungan digunakan nilai $\alpha$ sebesar 0,05 . Hasil penelitian menunjukkan bahwa masih banyak bayi yang menderita diare $(36,0 \%)$ dan bayi yang tidak diberikan ASI eksklusif secara penuh $(47,2 \%)$. Terdapat hubungan yang bermakna antara pemberian ASI eksklusif dengan kejadian diare pada bayi $(0,000)$, dimana ibu yang tidak memberikan ASI eksklusif pada bayinya berisiko lebih dari 8 kali untuk terkena diare dibandingkan dengan ibu yang memberikan ASI eksklusif untuk terkena diare pada bayinya. Diperlukan upaya pendidikan kesehatan tentang pentingnya pemberian ASI eksklusif, pencegahan dan penanganan awal diare pada bayi serta pendampingan pada ibu bayi dalam masa pemberian ASI eksklusif dengan melibatkan kader Posyandu dalam pelaksanaannya.

\section{Kata Kunci : Diare pada bayi, ASI eksklusif}

\section{PENDAHULUAN}

Bayi yang sehat ditunjukkan oleh pertumbuhan dan perkenbangan yang memadai. Namun seringkali dalam perjalanan masa kurun waktu itu bayi sering kali mengalami gangguan pertumbuhan dan perkembangan yang disebabkan oleh adanya penyakit yang menyertai, diantaranya bayi menderita diare.

Diare adalah dimana bayi buang air besar dengan konsistensi lebih lunak atau lebih cair dari biasanya dan terjadi paling sedikit tiga kali dalam 24 jam sehari. Kejadian diare khususnya di Negara berkembang termasuk Indonesia masih tergolong tinggi, baik secara nasional maupun wilayah.

Studi pendahuluan di wilayah kerja Puskesmas Cibadak Kabupaten Lebak pada tahun 2018 masih ditemukan bayi sebesar $16 \%$ menderita diare. Keadaan ini menjadi keprihatinan mengingat dampak diare terutama jika terjadi dehidrasi sangat berbahaya bagi kesehatan bayi bahkan dapat mengancam kehidupan bayi.

Dewasa ini sudah banyak kebijakan maupun program dan kegiatan dijalankan oleh pemerintah dalam hal ini Kementerian Kesehatan RI untuk menanggulangi diare pada bayi, salah satunya dengan mendorong pentingnya pemberian ASI eksklusif pada bayi sekurang-kurangnya dberikan pada bayi sampai berusia enam bulan dan disempurnakan sampai bayi berusia dua tahun.

Namun dilapangan menunjukkan cakupan ASI eksklusif masih belum menggembirakan, dan pada saat yang sama ibu masih banyak yang memberikan susu formula atau makanan lain selain ASI yang diberikan terlalu dini yang memicu masuknya kuman kedalam tubuh bayi.

Kondisi ini tentu sangat memprihatinkan yang jika tidak mendapat perhatian dan penanganan yang baik, tentu akan memberi 
implikasi terhadap status kesehatan bayi, dan rendahnya daya saing masyarakat. Karenanya perlu dicari upaya yang lebih efektif melalui penelusuran lebih jauh terkait dengan factor yang mempengaruhi kejadian diare pada bayi dan seberapa pengaruh pemberian ASI eksklusif terhadap kejadian diare pada bayi.

\section{METODE}

Penelitian ini merupakan penelitian analitik desain observasional dengan pendekatan pontong lintang (cross sectional). Populasi dalam penelitian ini ialah seluruh ibu yang memiliki bayi berumur 7 sampai 12 bulan di wilayah kerja Puskesmas Cibadak kapupaten Lebak sebanyak 572, dengan jumlah sampel sebanyak 89.

Pengambilan sampel dengan teknik proportional random sampling pada sembilan desa di wilayah kerja Puskesmas Cibadak Kabupaten Lebak. Variabel independen ialah pemberian ASI eksklusif dan variabel dependen ialah kejadian diare pada bayi.

Penelitian dilaksanakan wilayah kerja Puskesmas Cibadak Kabupaten Lebak pada bulan Juli sampai November 2019. Untuk mendapatkan data yang diperlukan, digunakan instrumen berupa koesioner. Mahasiswa jurusan kebidanan Rangkasbitung Poltekkes Kemenkes Banten dilibatkan sebagai enumerator dan bidan pembina desa di wilayah kerja Puskesmas Cibadak Kabupaten Lebak. Adapun teknik pengumpulan data dilakukan dengan cara wawancara terhadap sampel terpilih.

Pengelolaan dan analisis data dilakukan dengan bantuan perangkat komputer program SPSS. Analisis data dilakukan secara bertahap, yaitu univariat dan bivariat. Uji statistik digunakan uji $C h i$ Square. Untuk mengetahui kemaknaan hubungan antara variabel independen dan dependen digunakan nilai alpa $(\alpha)$ sebesar 0,05 . Penelitian ini sudah mendapat ijin Komisi Etik Penelitian Kesehatan Poltekkes Kemenkes Semarang dengan nomor 188/EA/KEPK/2019.

\section{HASIL DAN PEMBAHASAN}

1. Kejadian Diare Pada Bayi

Tabel 1 : Distribusi Ibu Bayi Berdasarkan Kejadian Diare Pada Bayi

\begin{tabular}{lcc}
\hline Kejadian Diare & Frekwensi & Presntase \\
\hline Diare & 32 & 36 \\
\hline Tidak Diare & 57 & 64 \\
\hline Total & 89 & 100 \\
\hline \multicolumn{3}{c}{ Berdasarkan } \\
tabel & 1 & diatas \\
menunjukkan bahwa masih banyak & $(36,0 \%)$ \\
bayi yang menderita diare.
\end{tabular}




\section{Pemberian ASI Eksklusif}

Tabel 2 : Distribusi Ibu Bayi

Berdasarkan Pemberian ASI Eksklusif

Pemberian ASI Frekwensi Presntase Eksklusif

\begin{tabular}{|c|c|c|}
\hline Tidak ASI & 42 & 47,2 \\
\hline Eksklusif & & \\
\hline ASI Eksklusif & 47 & 52,8 \\
\hline Total & 89 & 100 \\
\hline
\end{tabular}

menunjukkan bahwa hampir separuhnya (47,2\%), ibu tidak memberikan ASI eksklusif pada bayinya.

\section{Pemberian ASI dan Kejadian Diare}

Tabel 3: Distribusi Ibu bayi Berdasarkan Pemberian ASI Eksklusif Dengan Kejadian Diare Pada bayi

\begin{tabular}{|c|c|c|c|c|c|}
\hline \multirow[b]{2}{*}{ Pemberian } & \multicolumn{2}{|c|}{ Kejadian Diare } & \multirow{5}{*}{ Jumlah } & \multirow{5}{*}{ Pvalue } & \multirow[b]{2}{*}{ OR } \\
\hline & Diare & Tidak & & & \\
\hline ASI & & Diare & & & \\
\hline \multirow{2}{*}{ Eksklusif } & & & & & CI \\
\hline & & & & & $(95 \%)$ \\
\hline Tidak ASI & 25 & 17 & 42 & \multirow{7}{*}{0,000} & \\
\hline \multirow[t]{2}{*}{ Eksklusif } & $(59,5 \%)$ & $(40,5 \%)$ & $(100,0 \%)$ & & \\
\hline & & & & & 8,403 \\
\hline ASI & 7 & 40 & 47 & & $(3,054-$ \\
\hline Eksklusif & $(14.9 \%)$ & $(85,1 \%)$ & $(100,0 \%)$ & & $23,122)$ \\
\hline \multirow[t]{2}{*}{ Total } & 32 & 57 & 89 & & \\
\hline & $(36,0 \%)$ & $(64,0 \%)$ & $(100,0 \%)$ & & \\
\hline
\end{tabular}

Berdasarkan tabel 3 diatas

menunjukkan bahwa bayi yang menderita diare pada ibu bayi yang tidak memberikan ASI eksklusif pada bayinya sebesar 59,5\%, lebih banyak proporsinya dibandingkan dengan bayi yang menderita diare pada ibu yang memberikan ASI eksklusif pada bayinya yaitu sebesar $14,9 \%$.

Hasil uji statistic dengan menggunakan Chi Square diperoleh nilai $\mathrm{p}$ sebesar 0,000, berarti secara statistic terdapat hubungan yang bermakna antara pemberian ASI eksklusif dengan kejadian diare pada bayi. Nilai OR diperoleh sebesar 8,403 , berarti bahwa ibu yang tidak memberikan ASI secara eksklusif pada bayinya berisiko lebih dari 8 kali lebih besar untuk kejadian diare pada bayinya dibandingkan dengan ibu yang menyusui secara eksklusif untuk kejadian diare pada bayinya.

Hasil penelitian ini menunjukkan bahwa masih banyak bayi yang menderita diare $(36,0 \%)$, lebih tinggi proporsinya dibandingkan dengan temuan Tamimi, Jurnalis dan Sulastri (2016) sebesar 19,5\%. Masih banyaknya bayi yang menderita diare menunjukkan bahwa kualitas kesehatan dan perawatan bayi yang belum memadai.

Diare merupakan salah satu penyakit saluran pencernaan yang sering dijumpai di masyarakat yaitu penyakit yang ditandai dengan buang air besar encer lebih dari tiga kali dalam sehari (WHO, 2009). Diare pada bayi umumnya karena bakteri, virus, parasite yang menyebar melalui makanan dan minuman yang tercemar atau kontak 
dengan tinja penderita. Diare adalah penyakit yang juga berhubungan atau berbasis lingkungan, yang factor utamanya adalah kontaminasi air oleh tinja yang berakumulasi dengan perilaku manusia tidak sehat.

Beberapa perilaku ibu yang dapat menyebabkan diare pada bayi, antara lain (1) ibu yang memberikan makanan pendamping ASI (MP ASI) terlalu dini (usis $<6$ bulan), (2) ibu yang menggunakan botol susu terbukti meningkatkan risiko diare karena sulitnya untuk membersihkan botol, (3) ibun yang menyimpan makanan dalam suhu kamar dan tidak menutupnya dengan baik, (4) ibu yang memberi bayi minum menggunakan air yang tercerman, (5) ibu yang tidak mencuci tangan setelah buang air besar atau membersihkan tinja anak, (6) ibu yang membuang tinja (termasuk tinja bayi) sembarangan. Jika bayi diare yang terus berlangsung dapat mengalami kehilangan air dan elektrolit dan selanjutnya akan menyebabkan dehidrasi.

Prescilia (2009) menjelaskan bahwa dehidrasi merupakan suatu gangguan dalam keseimbangan air yang disebabkan pengeluaran dalam tubuh melebihi pemasukan dalam tubuh sehingga jumlah air pada tubuh berkurang.

Jika bayi mengalami dehidrasi, perlu dipahami prinsip dalam penangannya, sebagaimana dikemukakan oleh Saifuddin et al (2014), yaiyu (1) segera tangani dehidrasi, (2) mencegah terjadinya syok, (3) menjaga jalan nafas tetap bebas, (4) memperbaiki curah jantung, (5) mencari factor penyebab, (6) mengobati penyebab, (7) mencegah terjadinya kejang.

Hal lain yang tidak kalah penting dalam penanganan diare adalah menerapkan perilaku hidup sehat melalui upaya pencegahan, yaitu (1) memebrikan bayi ASI eksklusif selama enam bulan dan diteruskan sampai 24 bulan, (2) memberikan bayi minum menggunakan air yang direbus matang dan menggunakan air bersih, (3) memberikan bayi makanan pendamping ASI sesuai umur, yaitu pada umur 6-24 bulan, (4) mencuci tangan ibu dan bayi dengan air dan sabun sebelum dan sesudah buang air besar, (5) membuang tinja bayi dengan benar, (6) memberikan bayi imunisasi campak.

Penelitian ini juga menemukan bayi yang mendapat ASI eksklusif di wilayah kerja Puskesmas Cibadak sebesar 52,8\%, berarti masih ada bayi sebanyak 47,2\% tidak mendapat ASI eksklusif. Lebih tinggi proporsinya jika dibandingkan dengan temuan di wilayah Puskesmas Nanggalo Padang, tahun 2016, yaitu dimana bayi yang diberikan ASI eksklusif masih jauh 
dari target Nasional sebesar $80 \%$ diharapkan bayi mendapat ASI eksklusif.

Hampir separuhnya $(47,2 \%)$ bayi tidak mendapat ASI eksklusif menunjukkan bahwa perhatian tentang pentingnya asupan nutrisi pada bayi besar kemungkinan karena belum sepenuhnya dipahami dan dipraktikan oleh ibu bayi. Padahal bayi yang mendapat ASI eksklusif akan mendapat banyak manfaat. Adiningrum (2014) menjelaskan lebih lanjut bahwa ASI memiliki banyak manfaat untuk bayi, karenanya disarankan untuk menyusui bayi secara eksklusif selama enam bulan dan tetap melanjutkan menyusui sampai usia anak dua tahun.

Bayi yang diberi ASI akan lebih sehat dibandingkan dengan bayi yang diberi susu formula, karena pemberian susu formula pada bayi dapat meningkatkan risiko infeksi saluran kemih, saluran pencernaan, dan telinga. Bayi juga dapat mengalami diare, sakit perut (kolik), alergi makanan, asma, diabetes dan penyakit saluran pencernaan.kronik. Sebaliknya bayi yang mendapat ASI akan membantu mengoptimalkan perkembangan system saraf serta perkembangan otak bayi.

Kandungan dalam ASI luar biasa dan tidak terdapat pada jenis susu manapun. Bayi hampir tidak pernah alergi terhadap ASI (Muslihatun, 2010). ASI merupakan susu terbaik untuk bayi, tidak perlu disangsikan lagi. Disamping zat-zat yang terkandung didalamnya, pemberian ASI juga memiliki beberapa keutungan, yakni (1) steril, aman dari pencemaran kuman, (2) selalui tersedia dengan suhu yang normal, (3) produksi sesuai dengan kebutuhan bayi, (4) mengandung antibody yang dapat menghambat pertumbuhan kuman atau virus, (5) bahaya alergi tidak ada (Seotjiningsih, 1997).

Lebih lanjut Soetianingsih menjelaskan bahwa bayi yang mendapat ASI dengan cara menyusui bayi mendapat keutungan, (1) terjalin hubungan yang lebih erat antara bayi dan ibunya karena secara alami dengan adanya kontak kulit bayi merasa aman. Hal ini sangat penting bagi perkembangan psikis dan emosi dari bayi, (2) menyebabkan uterus berkontraksi sehingga mengembalikan uterus ke keadaan fisiologis (sebelum kehamilan) lebih cepat, (3) perdarahan setelah melahirkan tipe lambat berkurang, (4) akan mengurangi kemungkinan menderita kanker payudara pada masa mendatang, (5) kesuburan ibu akan berkurang untuk beberapa bulan (membantu program keluarga berencana).

Untuk keberhasilan pemberian ASI pada bayi diperlukan kiat-kiat pemberian ASI dan cara menyusui yang benar. Adiningrum (2014) menjelaskan kiat-kiat 
pemberian ASI pada bayi, yaitu (1) mulailah dengan perasaan santai dan bahagia, (2) berikan ASI sejak hari pertama, jangan berikan susu formula. Selingan susu botol menyebabkan produksi ASI terhambat dan bayi enggan menghisap payudara, (3) mulailah menyusui dengan satu payudara selama lima menit, kemudian berangsur bertambah lama dengan satu atau dua payudara, tergantung selera bayi dan produski ASI, (4) berikan ASI sebanyaj bayi inginkan, tidak perlu dijadwal. Setelah beberapa minggu bayi dapat mengatur jadwalnya sendiri, (5) buatlah bayi sendawa setelah menyusui. Ini diperlukan dalam bulan-bulan pertama. Setelah enam bulan, hal ini tidak diperlukan lagi karena biasanya bayi sudah dapat bersendawa sendiri, (6) makanlah dengan teratur dan dengan nilai gizi yang baik. Jangan makan makanan yang pedas, asam, atau menimbulkan gas. Selama mendapat ASI, bayi tidak perlu mendapat tambahan vitamin dan mineral. Jangan minum obat tanpa petunjuk dokter selama ibu memberikan ASI.

Cara menyusui yang benar perlu diperhatikan untuk keberhasilan menyusui, yaitu (1) bersihkan kedua tangan dengan menggunakan sabun atau cairan antiseptik sebelum menyusui, (2) pencet puting susu dan keluarkan sedikit ASI, kemudian oleskan pada areola untuk melembabkan dan membersihkan payudara, (3) duduk atau tidurlah dalam posisi yang nyaman. Tekuklah sebelah tangan, letakan kepala bayi pas dilengkungan siku. Tahanlah bokong bayi dengan telapak tangan dan satu tangan lainnya.

Hasil uji hubungan penelitian ini, menunjukkan bahwa terdapat hubungan yang bermakna antara pemberian ASI eksklusif dengan kejadian diare $(\mathrm{p}=0,000)$, dimana ibu yang tidak memberikan ASI secara eksklusif pada bayinya memiliki risiko lebih dari delapan kali lebih besar untuk menderita diare pada bayinya, dibandingkan dengan ibu yang menyusui secara eksklusif untuk menderita pada bayi. Hasil penelitian sama dengan hasil penelitin yang dilakukan oleh Tamimi, Jurnalis dan Sulastri (2016), yaitu terdapat hubungan antara pemberian ASI eksklusif dengan kejadian diare pada bayi di wilayah Puskesmas Nanggalo Padang ( $\mathrm{p}=0,014)$.

Hasil penelitian ini memberi informasi bahwa salah satu upaya untuk mencegah diare pada bayi adalah dengan mempraktikan perilaku menyusui/memberi kan ASI pada bayi secara eksklusif setidaknya selama enam bulan dan dapat dilanjutkan sampai dua tahun.

Untuk sampai pada pembiasaan berprilaku memberikan ASI secara eksklusif diperlukan upaya-upaya mulai dari 
peningkatan pengetahuan, sikap bagi ibu dan pasangannya akan pentingnya ASI bagi kesehatan bayi serta praktik menyusui yang benar serta pendampingan ibu selama penguatan sikap dan perilaku menyusui, setidaknya dalam kurun waktu enam bulan tahun pertama kehidupan bayi.

\section{SIMPULAN}

Berdasarkan tujuan dan hasil penelitian, dapat disimpulkan sebagai berikut :

1. Masih banyak bayi yang menderita diare $(36,0 \%)$ di wilayah kerja Puskesmas Cibadak Kabupaten Lebak pada tahun 2019.

2. Hampir separuhnya $(47,2 \%)$ ibu bayi tidak memberikan ASI secara eksklusif pada bayinya di wilayah kerja Puskesmas Cibadak Kabupaten Lebak tahun 2019.

3. Terdapat hubungan yang bermakna antara pemberian ASI eksklusif dengan kejadian diare pada bayi $(\mathrm{p}=0,000)$, dimana ibu yang tidak memberikan ASI secara eksklusif berisiko lebih dari delapan kali lebih besar untuk terkena diare pada bayinya, dibandingkan dengan ibu yang menyusui secara eksklusif untuk terkena diare pada bayinya.

\section{UCAPAN TERIMA KASIH}

Ucapan terima kasih disampaikan kepada Poltekkes Kemenkes Banten dan Puskesmas Cibadak Kabupaten Lebak yang telah memfasilitasi kegiatan penelitian ini.

\section{DAFTAR PUSTAKA}

Adiningrum, A., 2014. Buku Pinter ASI Eksklusif, Cetakan Pertama, Jakarta : Salsabila

Behrman R.E \& Vaughan V.C. 1988. Nelson Ilmu Kesehatan Anak : Nelson : Teksbook of Pediatric, edisi 12 Bagian 1, Jakarta : Buku Kedokteran EGC

Kementerian Kesehatan RI. 2015. Rencana Strategis 2014-2019, Kementerian Kesehatan RI

Marliandiani Y \& Ningrum Ny P. 2015. Buku Ajar Asuhan Kebidanan pada Ibi Nifas dan Menyusui, Jakarta : Salemba Medika

Maryuni A. 2017. Asuhan Ibu dan Nifas \& Asuhan Ibu Menyusui, Bogor: In Media

Muslihatun, WN. 2010. Asuhan Neonatus Bayi dan Balita, Yogyakarta : Fitramaya

Puskesmas Cibadak, Laporan Kinerja Puskesmas Cibadak Kabupaten Lebak tahun 2018.

Saifuddin, et all. 2014, Buku Acuan Pelayanan Kesehatan Maternal dan Neonatal, Jakarta : PT Bina Pustaka Sarwono Prawiroharjo

Saryono. 2011. Metodologi Penelitian Kesehatan, Yogyakarta : Mitra Cendikia Press.

Soetjiningsih. 1997. ASI : Petunjuk Untuk Tenaga Kesehatan. Cetakan I, Jakarta: Buku Kedokteran EGC

Tamimi M.A, Jurnalis, Y.D, Sulastri. D, 2016. Hubungan Pemberian ASI Eksklusif dengan Kejadian Diara pada Bayi di Wilayah Puskesmas Nanggalo Padang, Jurnal Kesehatan AndalasAndalas Journal of Health. 